\title{
Rancang Bangun Sistem Pakar Pendiagnosa Penyakit Paru-Paru Menggunakan Metode Case Based Reasoning
}

\author{
Diki Andita Kusuma ${ }^{1}$ Chairani $^{2}$ \\ 1,2 Jurusan Teknik Informatika, IBI Darmajaya \\ ${ }^{1,2}$ Jl. A. Pagar Alam, No. 93, Bandar Lampung, Indonesia \\ dikindk7@gmail.com, chairani.fauzi.fathir@gmail.com
}

\begin{abstract}
Abstrak - Penelitian ini membahas tentang pembuatan sistem pakar yang dapat digunakan untuk mendiagnosa penyakit paru-paru. Metode yang digunakan adalah metode Case Base Reasoning (CBR). CBR merupakan salah satu metode yang menggunakan pendekatan kecerdasan buatan (Artificial Intelligent) dan menitikberatkan pemecahan masalah dengan didasarkan pada knowledege dari kasus-kasus sebelumnya. Kasus-kasus yang digunakan diperoleh dari catatan penangan kasus diagnosa penyakit paru dari seorang dokter spesialis paru sebanyak 8 kasus dan disediakan satu buah kasus baru untuk dihitung nilai kedekatannya dengan kasus lama. Hasil dari penilitian ini memberikan keluaran berupa kemungkinan penyakit dan saran pengobatan yang didasarkan pada kemiripan kasus baru dengan pengetahuan yang dimiliki sistem. Nilai kedekatan dari 8 kasus lama terhadap kasus baru dari seorang pasien adalah 0.38 terhadap data kasus pertama, 0.45 terhadap data kasus kedua, 0.56 terhadap data kasus ketiga, 0.56 terhadap data kasus keempat, 0.72 terhadap data kasus kelima, 0.93 terhadap data kasus keenam, 0.52 terhadap data kasus ketujuh, dan 0.66 terhadap data kasus kedepelapan. Nilai kedekatan paling maximum diperoleh terhadap data kasus keenam, yaitu sebesar 0.93 atau 93\%, sehingga dapat disimpulkan bahwa pasien didiagnosa terserang penyakit radang paru.
\end{abstract}

Kata kunci- Sistem Pakar, Case Based Reasoning, Penyakit Paru-Paru

Abstract - This research discusses expert system that can be used to diagnose lung disease. The research use Case Base Reasoning (CBR) method. CBR is one of method that use artificial intelligence approach (AI) and emphasizes the problem solving based on knowledege of previous cases. The cases used were obtained from the cases records of lung disease diagnosis from a pulmonary specialist doctor as much as 8 cases and provided a single new case for the calculated value of its proximity to the old case. The results of this research provide the output of the disease possibility and treatment suggestions based on the similarity of new cases with knowledge of the system. Value of proximity of 8 old cases against new cases of a patient was 0.38 for the first case data, 0.45 for the second case data, 0.56 for the third case data, 0.56 for the fourth case data, 0.72 for the fifth case data, the data is 0.93 for the sixth case, 0.52 of the seventh case data, and 0.66 to the last case data. Maximum proximity value of data obtained by the sixth case, which is 0.93 , or $93 \%$, so it can be concluded that patients diagnosed pneumococcal disease.

Keyword - Expert System, Case Based Reasoning, Lung Disease

\section{Pendahuluan}

Paru-paru sebagai pompa satu-satunya untuk sistem pernapasan adalah organ yang sangat penting bagi berlangsungnya kehidupan. Namun masih banyak orang yang kurang peduli dengan kesehatan paru-paru, hal ini menyebabkan banyak orang yang terindikasi menderita penyakit paru-paru, antara lain Tuberkolosis, Bronkitis, PPOK (Penyakit Paru Obstrukti Kronis), dan Pneumonia (radang paru-paru) [2]. Banyaknya jumlah penderita paru-paru dengan jumlah dokter spesialis paru-paru yang tidak seimbang menyebabkan banyak pasien penderita paru-paru harus berlama-lama menunggu dokter spesialis datang. Selain itu penderita penyakit paru-paru juga harus mengeluarkan biaya yang mahal untuk berkonsultasi dengan dokter spesialis. Sistem pakar (expert sistem) adalah sistem yang berusaha mengadopsi pengetahuan manusia ke komputer, agar komputer dapat menyelesaikan masalah seperti yang biasa dilakukan oleh para ahli [4]. Salah satu alternatif penggunaan sistem pakar untuk membantu mendiagnosa gejala awal penyakit paruparu yaitu dengan metode Case Based Reasoning (CBR). Sistem ini dapat digunakan di puskesmas sebagai asisten dokter umum. Dengan adanya sistem ini diharapkan dapat membantu dalam mendiagnosa gejala awal penyakit paru-paru pasien tanpa perlu datang ke dokter spesialis melainkan hanya perlu datang ke puskesmas terdekat dengan biaya yang relatif lebih murah.

\section{Metodologi}

A. Metode Kajian

Case Based Reasoning (CBR) menggunakan pendekatan kecerdasan buatan (Artificial Intelligent) 
yang menitikberatkan pemecahan masalah dengan didasarkan pada knowledege dari kasus-kasus sebelumnya [1]. Secara umum, metode ini terdiri dari 4 langkah (gambar 1), yaitu:

\section{Retrieve}

Pada saat terjadi permasalahan baru, pertamatama sistem akan melakukan proses Retrieve. Proses ini akan melakukan dua langkah pemrosesan, yaitu pengenalan masalah dan pencarian persamaan masalah pada database.

2. Reuse

Proses ini sistem akan menggunakan informasi permasalahan sebelumnya yang memiliki kesamaan untuk menyelesaikan permasalahan yang baru dan menggunakan kembali informasi dan pengetahuan dalam kasus tersebut untuk mengatasi masalah. Pada proses Reuse akan menyalin, menyeleksi, dan melengkapi informasi yang akan digunakan.

Kriteria untuk pemilihan kasus adalah kasus yang memiliki kemiripan paling tinggi dengan kasus baru yang akan disarankan sebagai solusi Walaupun demikian, setiap kasus baru belum tentu memiliki nilai kemiripan yang lumayan tinggi dengan basis kasus [5]. Maka perlu diberikan kriteria kemiripan dengan menghitung nilai desimal dari setiap total atau nilai kemiripan seperti yang ditunjukkan pada Tabel 1.

Tabel 1. Kriteria kemiripan

\begin{tabular}{cc}
\hline Nilai Desimal Kemiripan & Kriteria Kemiripan \\
\hline $0.8-1$ & Tinggi \\
$0.4-7.9$ & Sedang \\
$0-0.3 .9$ & Rendah \\
\hline
\end{tabular}

3. Revise (meninjau ulang solusi yang diajukan).
Proses ini informasi tersebut akan dikalkulasi, dievaluasi, dan diperbaiki kembali untuk mengatasi kesalahan-kesalahan yang terjadi pada permasalahan baru.

4. Retain

Proses ini akan mengindeks, mengintegrasi, dan mengekstrak solusi yang baru. Selanjutnya, solusi baru itu akan disimpan ke dalam knowledge base untuk menyelesaikan permasalahan yang akan datang. Tentunya, permasalahan yang akan diselesaikan adalah permasalahan yang memiliki kesamaan dengannya.

Proses Retrive merupakan proses pencarian kemiripan kasus baru dengan kasus yang lama. Pencarian kemiripan antara kasus baru dengan kasus lama dilakukan dengan cara mencocokan gejala yang diinputkan oleh pengguna dengan gejala yang ada pada basis pengetahuan. Pada proses retrieve ini akan dilakukan pembobotan dengan menggunakan metode Nearest Neighbour.

\section{B. Algoritma Nearest Neighbor}

Nearest Neighbor adalah pendekatan untuk mencari kasus dengan menghitung kedekatan antara kasus baru dengan kasus lama, yaitu berdasarkan pada pencocokan bobot dari sejumlah fitur yang ada (1) [3]. Adapun rumus untuk melakukan penghitungan kedekatan antara dua kasus adalah sebagai berikut.

Similarity $(\mathrm{T}, \mathrm{S})=\frac{\sum_{i=1}^{n} f(T i, S i) x W i}{W i}$

T merupakan kasus baru, $\mathrm{S}$ merupakan kasus yang ada dalam penyimpanan, $\mathrm{n}$ menunjukkan jumlah atribut dalam setiap kasus, i adalah atribut individu antara 1 s.d. n, f merupakan fungsi similarity untuk fitur I dalam kasus $\mathrm{T}$ dan kasus $\mathrm{S}$, dan $\mathrm{W}$ menunjukkan bobot yang diberikan pada atribut ke-i.

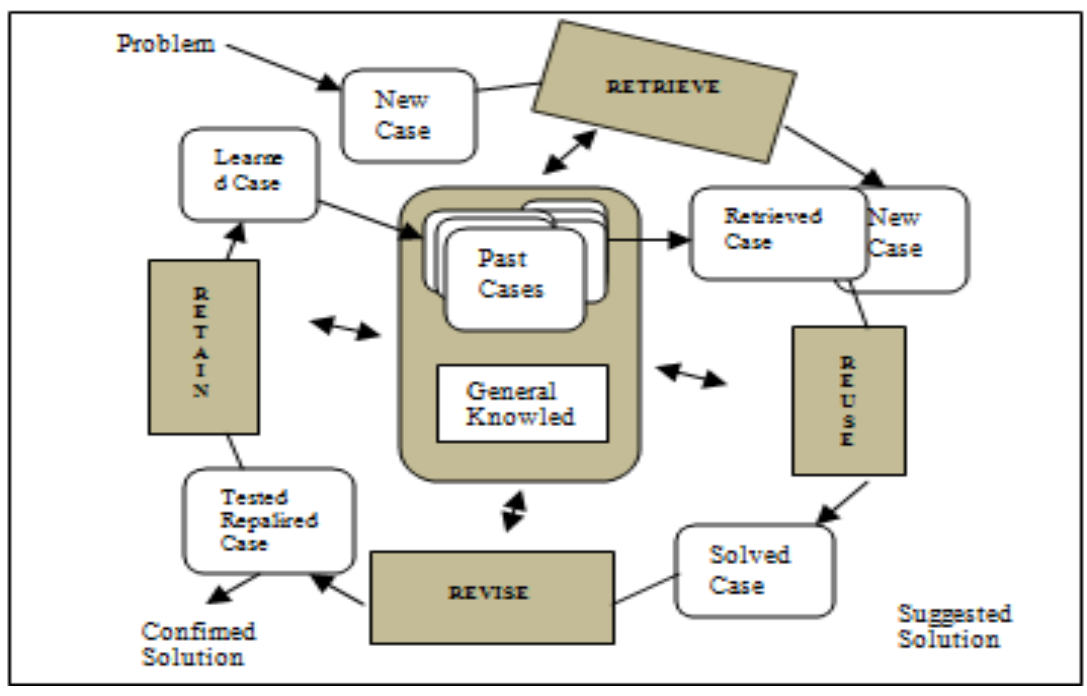

Gambar 1. Siklus metode CBR 


\section{PEMBAHASAN}

Untuk mempermudah mendiagnosa apakah seorang pasien baru menderita penyakit paru-paru atau tidak, dilakukan perhitungan berdasarkan kedekatan kasus lama (yang merupakan basis pengetahuan yang dimiliki oleh sistem dan pernah ditangani oleh seorang dokter paru-paru/pakar paru-paru) seperti yang ditunjukkan pada Gambar 2.

\begin{tabular}{|l|}
\hline Kasus lama : ID 0001 \\
\hline Batuk berdahak \\
Demam \\
Keluar keringat malam \\
Pilek \\
Flu \\
Diagnosa : \\
Penyakit Tuberkolosis \\
\hline Pengobatan : \\
Isoniazid $1 \times 1$ sehari \\
Rifampisin $1 \times 1$ sehari \\
Pirazinamid $1 \times 1$ sehari \\
etambutol 3x1 sehari \\
Streptomisin 1x1 sehari \\
\hline
\end{tabular}

\begin{tabular}{|l|}
\hline Kasus lama : ID 0004 \\
\hline Batuk berdahak \\
Sesak napas \\
Nyeri dada \\
Badan Lemas \\
Flu \\
Diagnosa: \\
Penyakit PPOK \\
\hline Pengobatan: \\
Ventolyn 1x1 sehari \\
Ambroxol 3x1 sehari \\
Azythomycin 1x1 sehari \\
\hline
\end{tabular}

\begin{tabular}{|l|}
\hline Kasus lama : ID 0007 \\
\hline Batuk berdahak \\
Sesak napas \\
Demam sedang \\
Badan Lemas \\
Pilek \\
Diagnosa : \\
Penyakit Bronkitis \\
\hline Pengobatan: \\
Erytromycin $3 \mathrm{x} 1$ sehar \\
Interhistin $3 \mathrm{x} 1$ sehari \\
Asammetelamat $3 \mathrm{x} 1$ sehari \\
Neurodex $1 \mathrm{x} 1$ sehari \\
\hline
\end{tabular}

\begin{tabular}{|l|}
\hline Kasus lama : ID 0002 \\
\hline Batuk berdarah \\
Demam \\
Keluar keringat malam \\
Nyeri bagian perut \\
Diagnosa : \\
Penyakit Tuberkolosis \\
\hline Pengobatan: \\
Isoniazid $1 \mathrm{x} 1$ sehari \\
Rifampisin $1 \mathrm{x} 1$ sehari \\
Pirazinamid $1 \mathrm{x} 1$ sehari \\
etambutol 3x1 sehari \\
Streptomisin $1 \mathrm{x} 1$ sehari \\
\end{tabular}

\begin{tabular}{|l|}
\hline Kasus lama : ID 0005 \\
\hline Batuk berdahak \\
Sesak napas \\
Demam tinggi \\
Wyeri dada \\
Mengiggil \\
Diagnosa: \\
Penyakit Radang Paru \\
\hline Pengobatan: \\
Binozyt $1 \mathrm{x} 1$ sehari \\
Dextrantolyn $3 \mathrm{x} 1$ sehari \\
Teopblyn $3 \mathrm{x} 1$ sehari \\
\hline
\end{tabular}

\begin{tabular}{|l|}
\hline Kasus lama : ID 0003 \\
\hline Batuk berdarah \\
Sesak napas \\
Nyeri dada \\
Badan Lemas \\
Nyeri bagian Perut \\
Diagnosa : \\
Penyakit PPOK \\
\hline Pengobatan : \\
Ventolyn 1x1 sehari \\
Ambroxol 3x1 sehari \\
Azythomycin 1x1 sehari \\
\hline
\end{tabular}

\begin{tabular}{|l|}
\hline Kasus lama : ID 0006 \\
\hline Batuk berdahak \\
Sesak napas \\
Demam tinggi \\
Nyeri dada \\
Pilek \\
Nyeri bagian perut \\
Diagnosa: \\
Penyakit Radang Paru \\
\hline Pengobatan: \\
Binozyt $1 \mathrm{x} 1$ sehari \\
Dextrantolyn 3x1 sehari \\
Teopblyn 3x1 sehari \\
\hline
\end{tabular}

Gambar 2. Contoh kasus-kasus penyakit paru-paru

Kemudian menghitung tingkat kemiriannya dengan kasus baru yang dimasukkan oleh pengguna (Tabel 2). Berdasarkan tingkat kemiripan yang diperoleh sistem akan mengeluarkan diagnosis penyakit yang diderita oleh pasien seperti yang ditunjukkan pada Gambar 3 dan Gambar 4.
Tabel 2. Contoh kasus baru

\begin{tabular}{|c|c|c|}
\hline 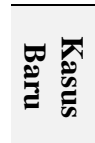 & $\begin{array}{l}\text { - Batuk berdahak } \\
\text { - Demam tinggi } \\
\text { - Sesak napas }\end{array}$ & $\begin{array}{l}\text { - Nyeri dada } \\
\text { - Nyeri bagian perut } \\
\text { - Menggigil }\end{array}$ \\
\hline
\end{tabular}

Menghitung kedekatan kasus baru dengan kasus 1 :

a. Kedekatan nilai atribut batuk ( berdahak dengan berdahak ) : 1 
b. Bobot atribut batuk : 1

c. Kedekatan nilai atribut sesak napas (ya dengan tidak) : 0

d. Bobot atribut sesak napas : 1

e. Kedekatan nilai atribut demam (tinggi dengan sedang) : 0.5

f. Bobot atribut demam :1

g. Kedekatan nilai atribut nyeri dada (ya dengan tidak) : 0

h. Bobot atribut nyeri dada : 0.75

i. Kedekatan nilai atribut keluar keringat malam (tidak dengan ya) : 0

j. Bobot atribut keluar keringat malam : 0.75

k. Kedekatan nilai atribut badan lemas (tidak dengan tidak) : 1

1. Bobot atribut badan lemas : 0.75

m. Kedekatan nilai atribut pilek (tidak dengan ya): 0

n. Bobot atribut pilek : 0.5

o. Kedekatan nilai atribut flu (tidak dengan ya): 0

p. Bobot atribut flu : 0.5

q. Kedekatan nilai atribut nyeri bagian perut ( ya dengan ya ) : 1

r. Bobot atribut nyeri bagian perut:0.5

s. Kedekatan nilai atribut menggigil (ya dengan tidak) : 0

t. Bobot atribut menggigil : 0.5

Jarak =

$\frac{((a * b)+(c * d)+(e * f)+(g * h)+(i * J)+k * l)+(m * n)+(o * p)+(q * r)+s * t))}{b+d+f+h+j+l+n+p+r+t}$

Jarak $=\frac{2.75}{7.25}$

Jarak $=0.3793$

Menghitung kedekatan kasus baru dengan kasus 2 :

a. Kedekatan nilai atribut batuk ( berdahak dengan berdarah ) : 0.5

b. Bobot atribut batuk :1

c. Kedekatan nilai atribut sesak napas ( ya dengan tidak ) : 0

d. Bobot atribut sesak napas :1

e. Kedekatan nilai atribut demam (tinggi dengan sedang ) : 0.5

f. Bobot atribut demam :1

g. Kedekatan nilai atribut nyeri dada (ya dengan tidak ) : 0

h. Bobot atribut nyeri dada : 0.75

i. Kedekatan nilai atribut keluar keringat malam (tidak dengan ya) : 0

j. Bobot atribut keluar keringat malam : 0.75

k. Kedekatan nilai atribut badan lemas (tidak dengan tidak) : 1

1. Bobot atribut badan lemas : 0.75

m. Kedekatan nilai atribut pilek (tidak dengan ya) : 0

n. Bobot atribut pilek : 0.5

o. Kedekatan nilai atribut flu (tidak dengan tidak) : 1

p. Bobot atribut flu : 0.5

q. Kedekatan nilai atribut nyeri bagian perut (ya dengan ya) : 1 r. Bobot atribut nyeri bagian perut:0.5

s. Kedekatan nilai atribut menggigil (ya dengan ya) $: 1$

t. Bobot atribut menggigil : 0.5

Jarak $=$

$\underline{((a * b)+(c * d)+(e * f)+(g * h)+(i * J)+k * l)+(m * n)+(o * p)+(q * r)+s * t))}$

Jarak $=\frac{3.25}{7.25}$

Jarak $=0.4483$

Hasil perhitungan kedekatan kasus lama dengan kasus baru selengkapnya pada Tabel 3 .

Tabel 3. Jarak kedekatan kasus lama gengan kasus baru

\begin{tabular}{ccc}
\hline No & Kasus Lama & Nilai Kedekatan \\
\hline 1 & ID 001 & 0.3793 \\
2 & ID 002 & 0.4483 \\
3 & ID 003 & 0.5517 \\
4 & ID 004 & 0.5517 \\
5 & ID 005 & 0.7241 \\
$\mathbf{6}$ & ID 006 & $\mathbf{0 . 9 3 1}$ \\
7 & ID 007 & 0.5172 \\
8 & ID 008 & 0.655 \\
\hline
\end{tabular}

Dari perhitungan terhadap 8 kasus lama yang ada, kasus yang memiliki bobot kemiripan paling rendah adalah kasus nomor 1 yaitu sebesar 0.3793 . Kasus yang menghasilkan bobot kemiripan paling tinggi adalah kasus nomor 6 yaitu sebesar 0.931. Pada proses reuse, solusi yang diberikan adalah solusi dengan bobot kemiripan kasus lama dengan kasus baru yang paling tinggi. Hasil perhitungan dengan bobot menunjukkan tingkat kepercayaan lebih dari $90 \%$ jadi solusi kasus no 6 yang direkomendasikan oleh sistem.

Pada proses revise dilakukan peninjauan kembali kasus dan solusi yang diberikan jika pada proses retrieve sistem tidak dapat memberikan hasil diagnosa yang tepat. Pada kasus no 6 diatas sudah menghasilkan solusi dengan tingkat kepercayaan diatas $90 \%$. Jadi tidak perlu dilakukan proses revise. Tetapi jika ternyata setelah dilakukan proses perhitungan dan tidak ada kasus yang mirip dengan kasus baru tersebut maka dilakukan proses revise. Informasi berupa masukan gejala pada kasus baru yang tidak ditemukan kemiripannya dengan basis pengetauan (rule) tersebut akan ditampung pada suatu tabel khusus (tabel revise) yang selanjutnya akan dievaluasi dan diperbaiki kembali oleh pakar untuk menemukan solusi yang tepat. 


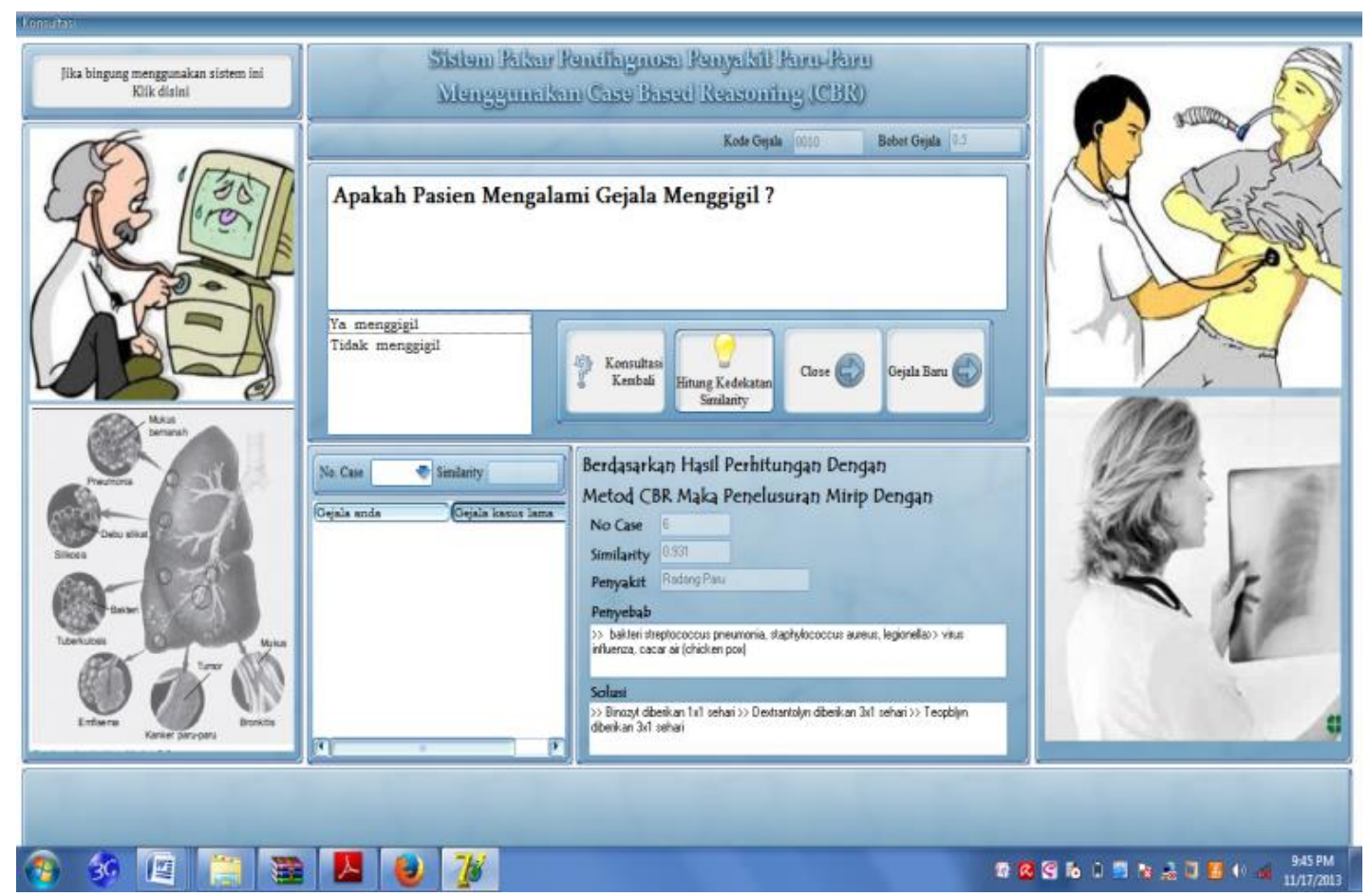

Gambar 3. Form konsultasi

\begin{tabular}{|c|c|c|c|}
\hline & \multicolumn{2}{|c|}{ Laporan Hasil Konsultasi } & \\
\hline NoCase & \multirow{2}{*}{$\begin{array}{l}1 \\
\text { Tuberkolosis }\end{array}$} & Tgl & 04-December-2012 \\
\hline Penyakit & & \multicolumn{2}{|c|}{ Similary } \\
\hline KGejala & Gejala & Bobot & Atribut \\
\hline 0001 & Batuk & 1.00 & Berdahak \\
\hline 0002 & Sesak Nafas & 1.00 & Tidak Sesak $N$ afas \\
\hline 0003 & Demam & 1.00 & Sedang \\
\hline 0004 & Nyeri Dada & 0.75 & Tidak Nyeri Dada \\
\hline 0005 & Keluar Keringat Malam & 0.75 & Ya Keluar Keringat Malam \\
\hline 0006 & Badan Lemas & 0.75 & Tidak badan lemas \\
\hline 0007 & Pilek & 0.50 & Ya pilek \\
\hline 0008 & Flu & 0.50 & Ya Flu \\
\hline 0009 & Nyri Bagian Perut & 0.50 & Ya nyeri bagian perut \\
\hline 0010 & Menggigil & 0.50 & Tidak menggigil \\
\hline
\end{tabular}

Case Cocol

NoCase $\begin{aligned} & 2 \\
& \text { Penyakit } \\
& \text { Tuberkolosis }\end{aligned}$
\begin{tabular}{|c|l|c|l|}
\hline KGejala & & Bobot & \multicolumn{1}{c|}{ Atribut } \\
\hline 0001 & Batuk & 1.00 & Berdarah \\
0002 & Sesak Nafas & 1.00 & Tidak Sesak Nafas \\
0003 & Demam & 1.00 & Sedang \\
0004 & Nyeri Dada & 0.75 & Tidak Nyeri Dada \\
0005 & Keluar Keringat Malam & 0.75 & Ya Keluar Keringat Malam \\
0006 & Badan Lemas & 0.75 & Tidak badan lemas \\
0007 & Pilek & 0.50 & Ya pilek \\
0008 & Flu & 0.50 & Tidak Flu \\
0009 & Nyri Bagian Perut & 0.50 & Ya nyeri bagian perut \\
0010 & Menggigil & 0.50 & Ya menggigil \\
\hline
\end{tabular}

Gambar 4. Laporan hasil konsultasi

Setelah proses revise selesai dan sudah ditemukan solusi yang benar-benar tepat oleh pakar barulah admin mulai menambah aturan dengan memasukkan data kasus baru yang sudah ditemukan solusinya tersebut ke dalam basis pengetahuan yang nantinya dapat digunakan untuk kasus berikutnya yang memiliki permasalahan yang sama. Proses inilah yang disebut dengan proses retain.

\section{PENUTUP}

\section{A. Kesimpulan}

1. Nilai kedekatan dari 8 kasus lama terhadap kasus baru dari seorang pasien adalah 0.38 terhadap data kasus pertama, 0.45 terhadap data kasus kedua, 0.56 terhadap data kasus ketiga, 0.56 terhadap data 
kasus keempat, 0.72 terhadap data kasus kelima, 0.93 terhadap data kasus keenam, 0.52 terhadap data kasus ketujuh, dan 0.66 terhadap data kasus kedepelapan.

2. Nilai kedekatan paling maximum diperoleh terhadap data kasus keenam, yaitu sebesar 0.93 atau 93\%, sehingga dapat disimpulkan bahwa pasien didiagnosa terserang penyakit radang paru.

\section{B. Saran}

Berdasarkan simpulan yang ada terdapat beberapa saran untuk dapat dikembangkan pada penelitian selanjutnya, yaitu :

1. Sistem yang dikembangkan memang terdapat tabel khusus untuk menampung kasus baru yang memiliki tingkat kemiripan yang rendah atau tidak memiliki kemiripan dengan kasus lama. Namun Tabel khusus tersebut tidak sampai ketahap evaluasi dan perbaikan oleh pakar, dikarenakan penelitian hanya berlaku 1 bulan. Setelah itu peneliti harus mengikuti prosedur penelitian dari awal jika ingin melakukan evaluasi dan perbaikan.

2. Untuk keamanan sebuah data diperlukan back-up data dan keamanan data (security).

\section{DAFTAR PUSTAKA}

[1] Andriana, 2008, Sistem Penalaran Komputer Berbasis Kasus (Case Based Reasoning-CBR), Yogyakarta, Ardana Media, p.17

[2] Junaidi, Iskandar, 2010, Penyakit Paru dan Saluran Napas, Jakarta, Bhuana Ilmu Popular

[3] Kusrini, Emha T. L., 2009, Algoritma Data Mining, Yogyakarta, Andi Offset . p. 93

[4] Kusumadewi, S. 2003. Artificial Intelligent (Teknik dan Aplikasinya). Yogyakarta: Graha dIlmu. p.109

[5] Muzid S., 2008, Teknologi Penalaran Berbasis Kasus (case based reasoning) untuk Diagnosa Penyakit Kehamilan, Yogyakarta, Universitas Islam Indonesia. p. 64 